The Sustainable City XII 185

\title{
SUSTAINABLE ARCHITECTURE: BUILDING DESIGN METHOD INTEGRATING USER'S COMFORT, ADAPTIVE BUILDING, PASSIVE OPTIMIZED BUILDING AND BUILDING INTEGRATED PV - EXPERIENCES FROM A UNIVERSITY COURSE
}

\author{
UDO DIETRICH \& MIRIAM POSSELT \\ REAP research group (Resource Efficiency in Architecture and Planning), \\ HafenCity University Hamburg, Germany
}

\begin{abstract}
Buildings are constructed to deliver users indoor comfort. There are two further requests to realize in the 21st century: Firstly, buildings should be carbon free, energy demand and supply of renewable energies should be in balance. Secondly, buildings should allow an adaptive use, users should have the possibility to control temperature, ventilation and lighting through comfort-relevant parts of the building. During a master course for students of architecture was investigated how to achieve these objectives and which design method is appropriate. Thus, a design method strictly following comfort criteria was applied. The assignment was to design an office building (moderate climate, Germany). The design method taught and experienced related main comfort criteria with the progressing building design. Shape of the building and shading by different parts of it determine the access of daylight to the later areas of usage. Size and placement of operable windows or separate openings determine natural ventilation, placement of desks determines if it is draught-free or not as well as the view out of the window. Window size and shading system determine overheating protection and the need of cooling systems. The remaining energy demand should be covered as much as possible by renewable energies gained on-site mainly by PV modules on the building's roof and façades. Then only in the last step the aesthetics of the building was regarded. The paper will report about all the different design steps with examples from student's works. A special chapter will deal with the experience of the students with that design process and if they assess it as a helpful method on their way of becoming architects.

Keywords: adaptive building, aesthetic, building design method, building integrated PV, comfort, education.
\end{abstract}

\section{GENERAL IDEA OF THE UNIVERSITY COURSE}

The design process of a building proceeds often in the way that first the shape of the building and its façade are developed not asking explicitly for comfort aspects of the later users. The result is also often sub-optimal in regard to energy demand.

To make students more conscious about that result they experience an "inverse" design method that starts from the users experience on his desk and thus from the interior to the exterior. Only at the end of the design process aesthetics is regarded. Of course, all participants knew this "inverse" design method alone is not appropriate, and that aesthetics has to be regarded also from the beginning on. But target of this course was to help students to find the right way between both opposite design methods, to overcome inhibitions and to make them capable of finding the best compromise fulfilling all targets in aesthetics, comfort and energy demand.

In regard to energy demand the chances to realize the 2020 target of a Zero-EnergyBuilding were investigated. For moderate climates, the demand for heating is quite well known from passive house literature. Much more interesting was the question if and how the 
remaining energy demand could be covered with PV modules on-site touching the topic of building integrated PV.

Supplementary, two more qualitative interviews with the participants were conducted. In the first one in the first week of the course they should describe their dream office; the questions had a (partly hidden) connection to comfort criteria. The results were used for the following building design. The second one was conducted at the end of the course, here students were asked about their opinion what contemporary architecture should show, if they feel well informed in their training as architects to do this work and how do they see their role as future architects. The results of the interviews are shown too; even if it is not a quantitative survey it gives a good impression following our experience (also of the situation at a department of architecture of a German main-stream university).

\section{DIDACTICAL APPROACH}

The course integrated 31 students from the third semester of a master program in architecture. Its value is $5 \mathrm{CP}$ (150 working hours) and it is held in one semester. It was structured as an interactive development of the design of an office building.

Students were organized in eight groups. To avoid a competition with too similar results and to foster a diversity of different but successful solutions the 8 groups dealt with the same task but on a different plot and location. The design process was separated in a sequence of steps. In each step corresponding input to comfort criteria and dimensioning of systems for the passive optimization of buildings was delivered. Each step ended with a short presentation of student groups where the other groups should discuss the findings of the presenting one. Special investigations of one group (to innovative shading systems e.g.) of common interest were interchanged with the other groups. It was a central target to form a collective of groups were each single group contributes to the process.

A step by step design process in architectural teaching is discussed in literature [1], more general in multi-author compilations [2], [3].

With each presentation, the work was commented and assessed by the supervisor so that the students had a quick feedback and knew where they were. The assessment as well as the design process were based on comfort criteria (see table 1). Therefore, clear and widely objective criteria for the assessment could be used for the students to recognize which task should be fulfilled next time.

The design process had an open end, the only request is human comfort but not a specially shaped architectural highlight - all results would be accepted as well done.

\section{SURVEY IN STUDENTS GROUPS - MY DREAM OFFICE}

Students of the course were handed a questionnaire to describe their dream office. It included questions about the office's ideal dimensions and orientation, furnishing, comfort adaptability, as well as properties of its windows openings and shading. The most favourable lookout, storey and the possibility of a dress code in combination with preferred temperature in summer were asked as well. Obviously, the questions corresponded with the design criteria of the class and summarized them.

Considering the dimensions of the dream office and number of fellow workers the answers had a wide range from single- to large offices with a preference at four to six people in one office. (This matches the "studio" - type offices of the task.) The furnishing should be both flexible and economical. Locating the desk close to a window is widely preferred. One third wishes storage area in the office room; a few wanted to incorporate a couch, a coffeemaker, presentation area, a community table, a designated coffee break area, individually adaptable furniture or a terrace to increase their comfort. 
There was no preference of a certain orientation. A generous glazing is favoured, $30 \%$ added opaque façade elements or a window to wall ratio of $50 \%$. The majority of $89 \%$ wish for a clear glazing (non-coloured).

According to $80 \%$ the shading system needed to let in natural daylight and allow a reduced view outside. Often an outside jalousie was mentioned, a third wants to add glare protection on the inside.

Table 1: Sequence of steps in the design process and relation to comfort criteria, comfort assessment and used methods/tools for assessment.

\begin{tabular}{|c|c|c|c|c|}
\hline $\begin{array}{l}\text { Phase of } \\
\text { building } \\
\text { design }\end{array}$ & $\begin{array}{l}\text { Aspect of } \\
\text { human comfort }\end{array}$ & Comfort assessment & $\begin{array}{l}\text { Method/tool for } \\
\text { assessment }\end{array}$ & $\begin{array}{l}\text { Description } \\
\text { in chapter }\end{array}$ \\
\hline \multirow[t]{3}{*}{$\begin{array}{l}\text { Building } \\
\text { shape and } \\
\text { depth }\end{array}$} & Daylight & $\begin{array}{l}\text { Daylight coefficient } \\
>=5 \% \text {, in minimum } \\
3 \%\end{array}$ & Geometrical rules & 5.1 \\
\hline & $\begin{array}{l}\text { View out of the } \\
\text { window }\end{array}$ & $\begin{array}{l}\text { Something to watch at } \\
\text { (no static view) }\end{array}$ & \multicolumn{2}{|l|}{$\begin{array}{l}\text { Visualization/descri } \\
\text { ption }\end{array}$} \\
\hline & Privacy & $\begin{array}{l}\text { Next part of the } \\
\text { building }\end{array}$ & \multicolumn{2}{|l|}{$\begin{array}{l}\text { Distance in } \\
\text { minimum } 20 \mathrm{~m}\end{array}$} \\
\hline $\begin{array}{l}\text { First ideas for } \\
\text { separation of } \\
\text { façades }\end{array}$ & $\begin{array}{l}\text { Natural } \\
\text { ventilation }\end{array}$ & $\begin{array}{l}\text { Air to breath, } \\
\text { Tempering of the } \\
\text { room } \\
\text { (night ventilation) }\end{array}$ & $\begin{array}{l}\text { Rules for necessary } \\
\text { size and placement } \\
\text { of ventilation } \\
\text { openings and shafts }\end{array}$ & 5.2 \\
\hline \multirow{3}{*}{$\begin{array}{l}\text { First ideas for } \\
\text { floor plans } \\
\text { and placement } \\
\text { of desks }\end{array}$} & $\begin{array}{l}\text { Draught-free } \\
\text { ventilation }\end{array}$ & $\begin{array}{l}\text { Necessary ventilation } \\
\text { openings not there } \\
\text { where the desks are }\end{array}$ & \multicolumn{2}{|l|}{ Visualization } \\
\hline & $\begin{array}{l}\text { Cooling breeze } \\
\text { in summer, } \\
\text { communication }\end{array}$ & $\begin{array}{l}\text { Supplementary } \\
\text { ventilation openings } \\
\text { exactly there where } \\
\text { the desks are }\end{array}$ & \multicolumn{2}{|l|}{ Visualization } \\
\hline & Visual comfort & $\begin{array}{l}\text { Placement of desks } \\
\text { near to windows }\end{array}$ & \multicolumn{2}{|l|}{ Visualization } \\
\hline \multirow[t]{3}{*}{$\begin{array}{l}\text { Façades and } \\
\text { shading } \\
\text { system }\end{array}$} & $\begin{array}{l}\text { Thermal } \\
\text { comfort in } \\
\text { summer }\end{array}$ & $\begin{array}{l}\text { Indoor temperatures } \\
\text { in comfortable range }\end{array}$ & $\begin{array}{l}\text { Adaptive comfort } \\
\text { model, transient } \\
\text { thermal simulation }\end{array}$ & 5.3 \\
\hline & Visual comfort & $\begin{array}{l}\text { View out of the } \\
\text { window also with } \\
\text { activated shading } \\
\text { system }\end{array}$ & \multicolumn{2}{|l|}{ Visualization } \\
\hline & Adaptive user & $\begin{array}{l}\text { Possibility to personal } \\
\text { control of all elements } \\
\text { that influence comfort }\end{array}$ & \multicolumn{2}{|l|}{$\begin{array}{l}\text { Description/ } \\
\text { visualization }\end{array}$} \\
\hline $\begin{array}{l}\text { Final design } \\
\text { of façades and } \\
\text { roof }\end{array}$ & $\begin{array}{l}\text { Aesthetics and } \\
\text { renewable } \\
\text { energy } \\
\text { production }\end{array}$ & $\begin{array}{l}\text { Human scale, } \\
\text { Zero-Energy-Building }\end{array}$ & $\begin{array}{l}\text { Modulor of } \\
\text { Corbusier, } \\
\text { Calculation of } \\
\text { harvested renewable } \\
\text { energy with web- } \\
\text { based tool }\end{array}$ & 5.4 and 5.5 \\
\hline
\end{tabular}



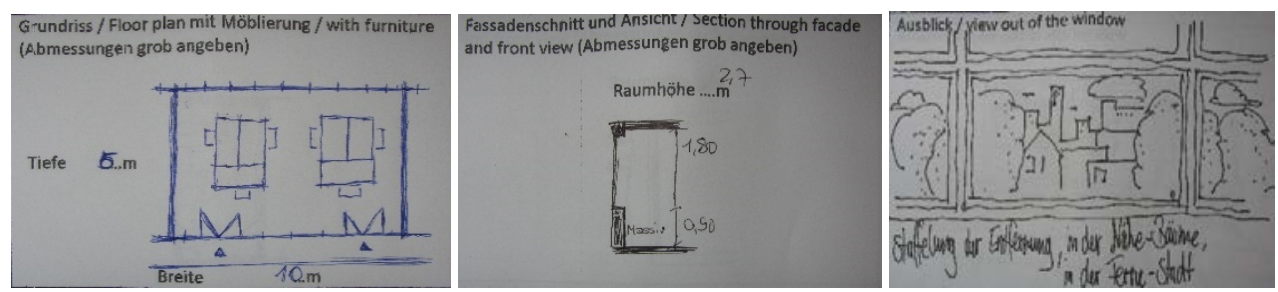

Figure 1: photos of sketches from questionnaires showing the most favoured situation [20].

Everyone wished for a dynamic view out of their window; which lead to two different types of view: about half of the students prefer a location from 1st to 4th floor looking at the city and vegetation; the other half aims for a wide view from 5th to 10th story all over the city.

Except for one student none desired a dress code but $54 \%$ could agree on a less strict, casual dress code, whereas $42 \%$ reject a dress code entirely. The ability to adapt all technical systems individually was desired $100 \%$ at ventilation openings, natural ventilation at about $83 \%$, shading at $90 \%$ and $75 \%$ at thermostats. Therefore $17 \%$ prefer mechanical ventilation and $20 \%$ a central operated thermostat. For tolerance of temperature it is desired that the inside temperatures varies slightly during the year corresponding to the outside temperature but are limited to $22^{\circ} \mathrm{C}$ to $25^{\circ} \mathrm{C}$, about $20 \%$ would accept a maximum temperature of up to $28^{\circ} \mathrm{C}$.

To meet the preferences from the dream-office-survey a building should be adaptable in general, meaning it can be regulated manually and personally but is supported by centralized systems. These systems therefore can be - but do not have to be - switched on additionally. During some transitional periods, e.g. the mechanical ventilation could be turned off because natural ventilation provides high comfort already. This variant can meet almost all criteria.

\section{GENERAL TASK FOR A NEW OFFICE BUILDING}

The student's task is the development of a medium office building of $10.000 \mathrm{~m}^{2}$ net floor area for an innovative company with well-motivated staff. The location should be in or near to one of the growing cities in Germany, well connected to public transport but in a nice surrounding. An estate of up to $15.000 \mathrm{~m}^{2}$ allowing each building shape was assumed as available.

The users know quite well what kind of building they want to have, perhaps because of some lacks in their old building and because they know well how they want to work together. General wishes are no sky scraper and no air conditioning. The building shall deliver highest comfort in regard to an excellent daylight situation and natural ventilation. There is no dresscode, users are ready to adapt to floating temperatures in hot summer periods and would accept also $28^{\circ} \mathrm{C}$ to $30^{\circ} \mathrm{C}$ in their rooms for a few hours in the year. The building shall allow an adaptive use, users want to have the possibility to control operable windows, ventilation flaps, light switches, thermostats etc.

The building contains two different types of offices, a standard type for administration (2 to 4 persons, $14 \mathrm{~m}^{2}$ per person) and a special "studio" - type with high equipment for the core units of the company, a number of creative working teams ( 6 to 8 persons, $18 \mathrm{~m}^{2}$ per person). Each of these studios should have its own character by shape, height, equipment etc., all studios should be linked by a circuit. 


\section{DESIGN APPROACH AND DIDACTICAL STEP BY STEP PROCEDURE}

5.1 First step - proposal for building shape, analysis of daylight situation, view out of the window, privacy

First groups should show their choice for the estate and propose per student one building shape (footprint and height) as different as possible. Statements for the design of outside facilities, local public infrastructure and positions of intermediate floor slabs and staircases should be made. The view out of the window to inner courts and the exterior should be shown by exemplary pictures. Students should analyse the pros and cons of the different proposals and decide for one building shape (or a synthesis of all) and give reasons for their decision. In a discussion in the whole group recommendations for the final decision were delivered.

Simple tools for the analysis of the daylight situation [5], [6], were delivered. The basic rule is that the daylight coefficient is $5 \%$ up to depth that is equivalent to the room height and $2 \%$ up to twice the room height. The recommended minimum window to wall ratio for cloudy sky in Germany is $50 \%$.

Access to the building and the connection to public transport were part of the investigation. But main subject of this step was just the shape of the building as a structural work without any consideration of the façades.

Fig. 2(a) shows for the same estate two different proposals for the building shape. After the analysis, the bottom one was chosen for further work. Fig. 2(b) shows the corresponding analysis of the daylight situation.

Central part of the discussion was to ensure an excellent daylight access to all main areas of usage by moderate room depths of about 5 to $6 \mathrm{~m}$ and an arrangement of different wings of the building in a way that daylight access is not limited by shadowing.

This analysis shows the potential of daylight access only as consequence of building shape and intermediate ceilings, no information about windows and façades is necessary.

\subsection{Second step - analysis of natural ventilation concept and visual comfort}

In the second presentation groups should develop a concept for natural ventilation and visualize it. A first estimation of the size of ventilation openings and their positioning relative to the working places should lead to first conclusions for the following dimensioning of the façades.

Perspectives of the interior room situation with equipment seen from a typical working place should demonstrate the reference to the other working places as well as the reached visual comfort, also for the view out of the window with exemplary pictures.

Natural ventilation has two driving forces, buoyancy and wind. If there is a temperature difference between inside and outside buoyancy wants to move the air vertically. To reach a sufficient velocity an acceleration path of some metres is necessary - best arrangement of ventilation openings is one with a big height difference. Thus, small and high openings in the façade are better than horizontal ones. Buoyancy reaches its full potential only with a height difference of $4 \mathrm{~m}$ and more - more than the standard height of office rooms. Thus, air change is further increased with ventilation through the roof of atria or ventilation shafts [5].

Wind wants to move air horizontally through the building. To reach efficient cross ventilation openings on both opposite façades are necessary and internal partition walls must contain corresponding openings to allow overflow [5].

The necessary size of openings for the different types of natural ventilation can be taken from a German standard for offices [7]. As a rule of thumb openings to deliver air to breathe 
need about $10 \%$ of the façade and those to temper the room (see 1.3 .3 here below) in minimum $50 \%$.

Ventilation openings can be operable windows but also separate, opaque flaps in the façade or the reveal. The relation between the possible location of desks and the position of ventilation openings should be carefully determined (see table 1). Fig. 3 shows proposals for size and positioning windows as well as ventilation flaps in the façade. All together save daylight, provide view out of the windows and allow all functions of natural ventilation.

Fig. 4(a) shows an example for cross ventilation and ventilation with big height differences through flaps in the separating walls to the floors. A very interesting architectural solution is the extension of floors in their width. Between the walkways on both sides an open-air space can act as vertical ventilation shaft. The roof of these mini-atria has ventilation flaps to exhaust air and can be transparent and deliver daylight to the floor zones as well (Fig. 4(b)). The total building depth increases but the gain in quality to stay there in a day lit communication zone should be worth it. Finally, the relation between windows, ventilation openings and the placement of desks was to clear up (see Fig. 5). Users should have the possibility to adapt the façade to their personal wishes and to enjoy a nice view out of the window.

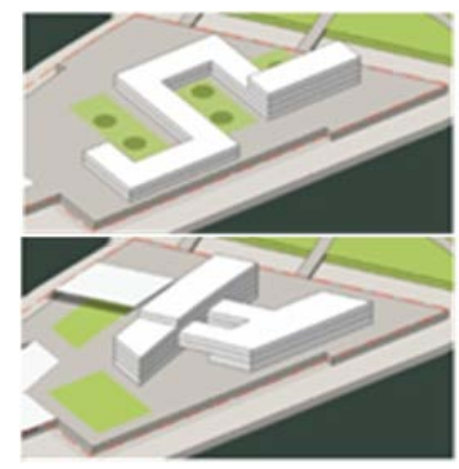

(a)

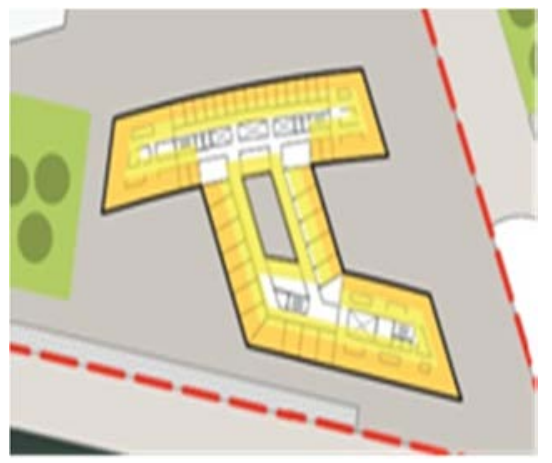

(b)

Figure 2: (a) Two different proposed building shapes [4]; (b) Daylight analysis of the chosen building shape [4].

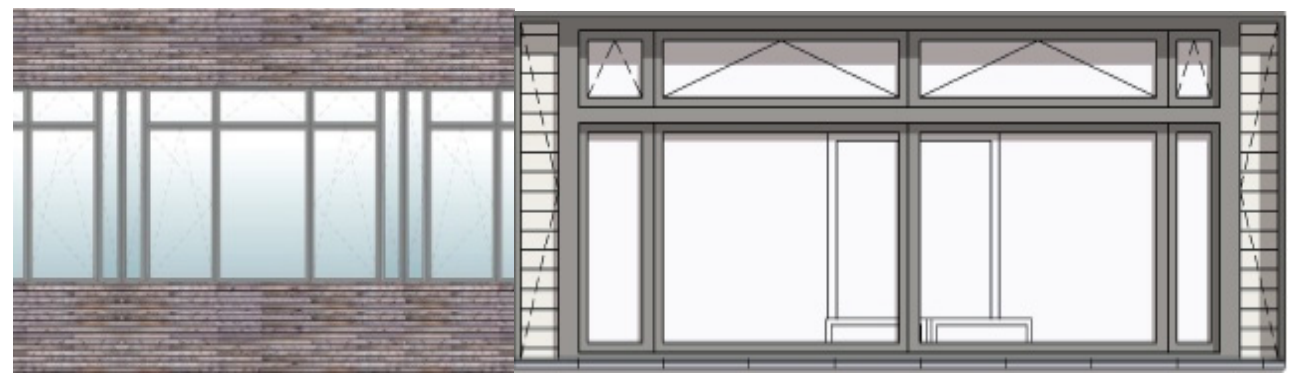

Figure 3: Arrangement of windows and separate ventilation openings in façades [8], [9]. 


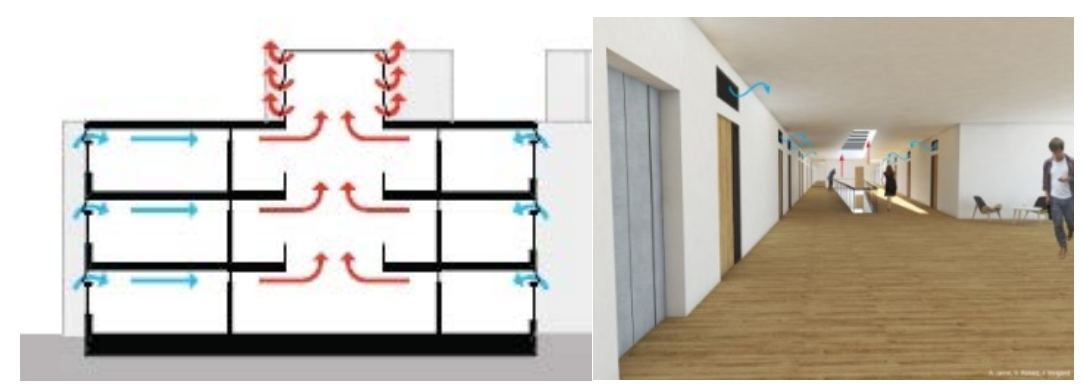

Figure 4: Principle (a) and perspective (b): of natural ventilation with big height difference using extended, floor zones as atria [10].

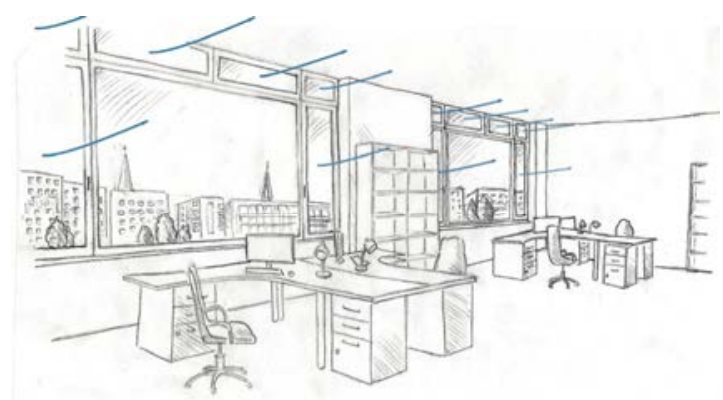

Figure 5: Possible desk-placement relative to windows and ventilation openings [11].

5.3 Third step - overheating protection and shading system; thermal and visual comfort in summer

The company has no dress-code, users can adapt to higher temperatures with their clothing. The building is adaptive with natural ventilation. Thus, everybody knows that temperatures indoor will be near to those outdoor. To prove that, selected critical rooms should be investigated with a transient simulation delivering the indoor temperatures in summer, they should be comfortable and fulfil the standard of the adaptive comfort model EN 15251 (energy plus based Primero-Comfort software [12], was used). The last parameters could be fixed: Strategy for natural ventilation, the optimal window size and the shading system. Finally, sections and elevations of the façades summarise placement of windows, ventilation openings and shading system. Last but not least the visual comfort for the view out of the window with an activated shading system should be demonstrated with exemplary pictures.

The main statement of EN 15251 is that in hot periods people feel well with temperatures that move slightly with outdoor temperatures. It defines 3 different comfort classes, whereas comfort class II is recommended for new buildings. A limited number of exceeding hours of 3 to $5 \%$ of yearly hours of use should be allowed (see Fig. 6).

Main target is the overheating protection or in other words thermal comfort also in hot periods. The necessary strategy for natural ventilation to temper the room in summer has to be found out. Fig. 7 shows a section through a façade with the integrated external shading system and the corresponding view onto the façade. 
Note that in the suspended ceiling is a horizontal ventilation shaft. It transports the air from the opposite room through the floor and the regarded room. The exhaust opening is hidden in the façade view. Fig. 8 shows a possible arrangement of desks relative to the façade and the resulting view out of the window without and with activated shading system.

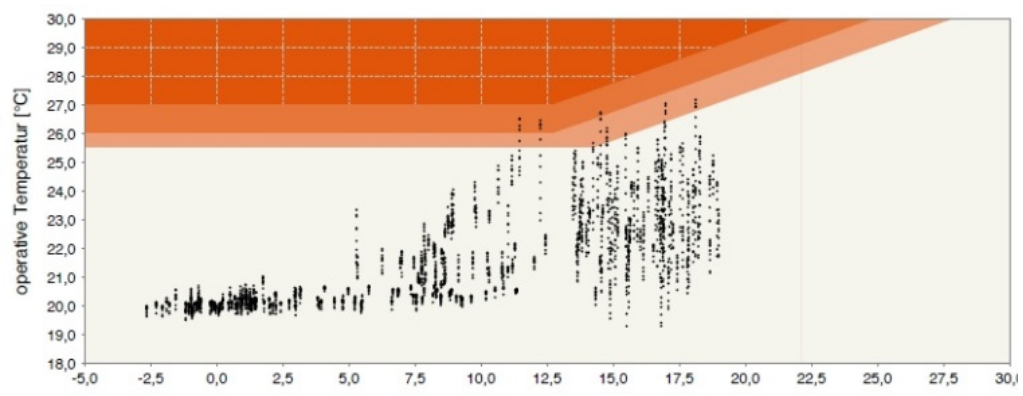

Figure 6: Example for assessment of indoor temperature according to adaptive comfort model EN 15251. Horizontal axis shows the daily mean value of outdoor temperature, vertical axis temperature indoor. Each point in the graph stands for one hour of usage. The three red fields represent the comfort categories to reach [12], [13].

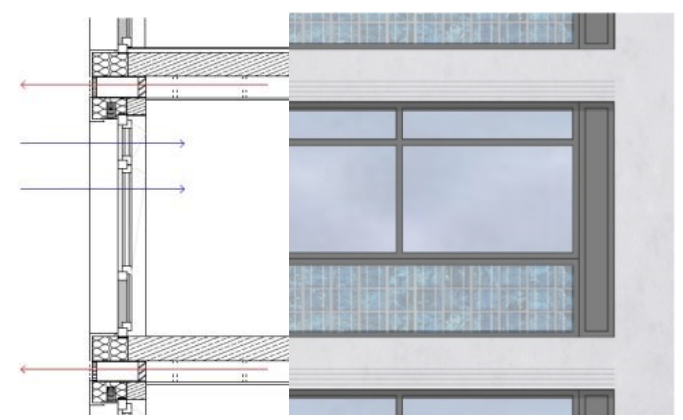

(a)

(b)

Figure 7: (a) Section through a façade with integrated external shading system; (b) Corresponding view on the façade [14].
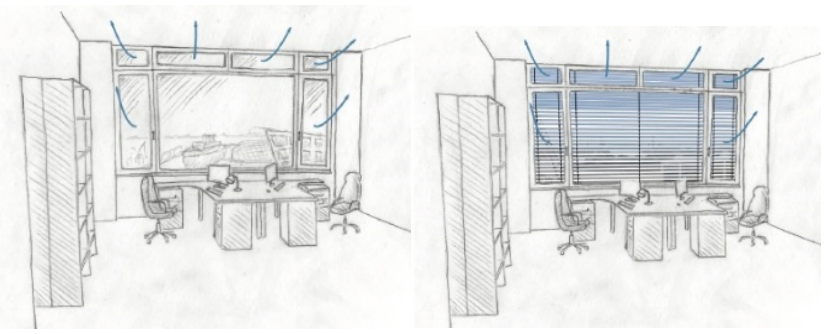

Figure 8: View out of the window without (left) and with (right) activated shading system [11]. 
The simulations of the student's groups showed that the maximum of $65 \%$ should not be exceeded otherwise problems with overheating would increase remarkably.

Under this precondition overheating protection could be realized with an intelligent strategy for natural ventilation and a corresponding shading system without hard changes in window size. For ventilation strategy, a high air change during the day was recognized as the most important criteria. That is because of the widely comfortable outside temperatures even in hot periods in cool northern part of Germany. For locations more in the south night ventilation and storage mass would become more important. External shading system is necessary. The best behaviour is shown by venetian blinds. With lamellas in cut off position enough daylight is transferred to avoid artificial light and it allows a (reduced) view out of the window.

\subsection{Fourth step - integration of active solar systems}

Possible areas for active solar systems on façades and roof of the building and on the estate should be located. The construction of modules and collectors should be defined. The energy demand of the building is estimated and compared with the prognosticated harvest of renewable energies. For the calculation of PV harvest PV-GIS [15], was recommended. For the assessment of the energy demand of the building a simple, self-developed excel sheet was delivered. The chances to reach a Zero-Energy-Building are assessed. Fig. 9 shows an example for the arrangement of PV modules on a roof. Fig. 10 shows possible arrangements for façade integrated PV modules.

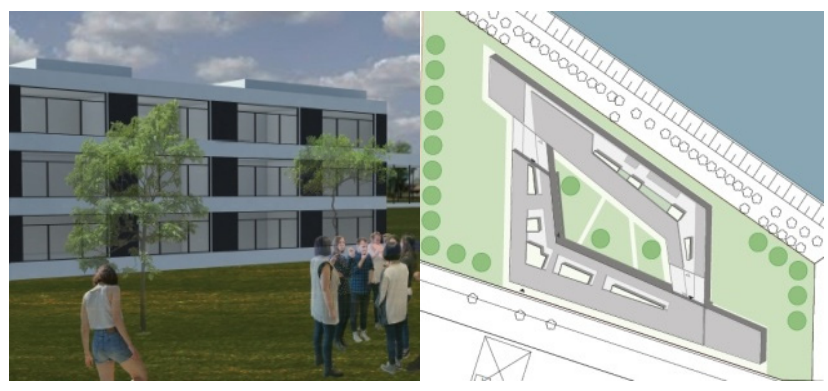

Figure 9: PV modules on building's roof [10]. Because of the roof landscape areas can't be filled with modules.

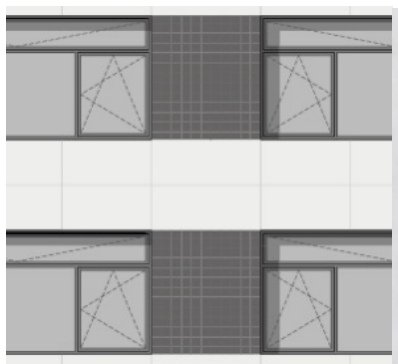

(a)

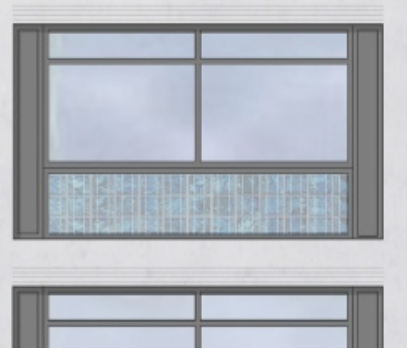

(b)

Figure 10: PV modules integrated in façades. (a) Between windows [10]; (b) As parapet [14]. 


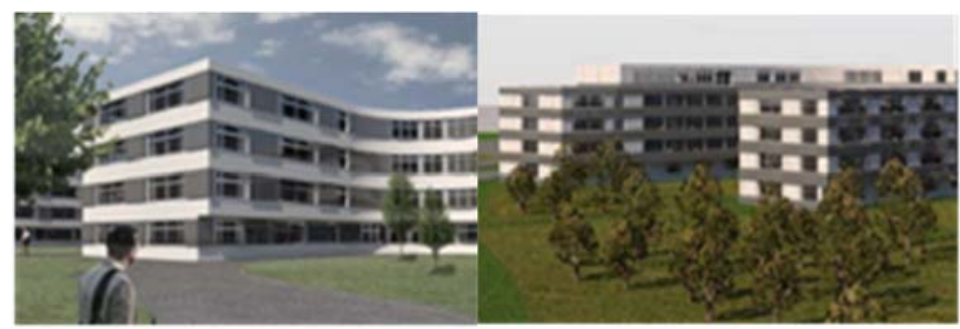

Figure 11: PV modules integrated in façades and design [9]. Left version was chosen.

There is a competition between the area of usage producing energy demand and the area of the roof and suitable façades for active systems. The higher the number of stories the less the possible area for active systems (still only one roof; façades have less insolation and are already used for windows and openings). Consequently, the different developed buildings showed different chances to reach a Zero-Energy-Building. Up to 3 stories it seems to be possible, for higher buildings not. The comparison between energy demand and the potential of harvesting renewable energies on-site showed that in first priority the energy demand should be further reduced down to a Passive House standard. Only then the potential for renewables is in the same range and a Zero-Energy-Building could be reached.

\subsection{Fifth step - final design of façades, materials and color}

Now and finally the students should deal with the design of the building, especially with the façades. Perspectives from the view of a pedestrian who is approaching to the building should demonstrate an impression of the building like it is. High qualities in façade design should be proved with a "zoom" onto the façade in 4 scales (about 1:200, 1:100, 1:50 and 1:20). Declarations to the choice of materials and a color concept complete the building design.

Fig. 11 demonstrates the final design process with aesthetical decisions where to place which element and how the façade shall look. PV modules play a central role in this context. The left variant with modules between the windows was assessed as more aesthetic and proposed for realization. Fig. 12 shows examples for the final design of the created office buildings.

Operable windows, ventilation flaps and shading systems create a lively and dynamic change in façade. Caused by the adaptive use where each user can adjust elements in the façade according to his personal wishes the view onto the façade shows a lively, dynamically changing picture. This dynamic can be explicitly shown and reinforced by different elements

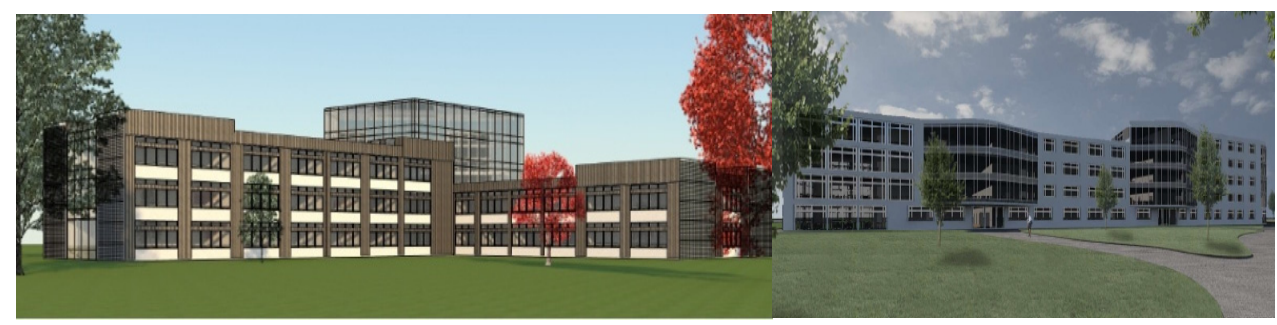

Figure 12: Perspectives of the building showing the final design ((a) [13]; (b) [9]). 


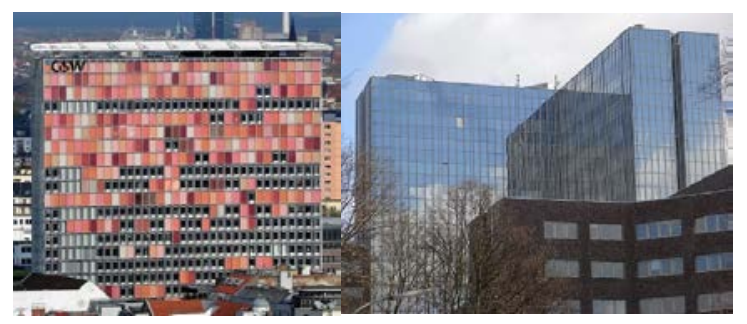

Figure 13: Examples for adaptive façades. (a) A dynamic façade [18]; (b) A static façade [19].

and colors. The contrary view point tries to hide this entire dynamic and to create a more static view onto the façade or the façade itself is sealed and static and does not allow adaptive use. An example for a dynamic façade is shown in Fig. 13(a) (GSW headquarter Berlin, Sauerbruch and Hutton), a static façade is shown in Fig. 13(b) (Alstercity building in Hamburg, Helmut Greve).

\section{EXPERIENCE, EVALUATION AND ACCEPTANCE OF THE COURSE BY STUDENTS}

After the course was finished the students answered an evaluation questionnaire. Students were asked about their view on certain future (global) challenges, sustainable architecture and their overall experience with the course, 23 questionnaires were analysed.

The first part of the survey asked for aspects of the world view and possible development. $78 \%$ agreed that the current generation of people was better off than their parent- or grandparent-generation, $18 \%$ disagreed and $4 \%$ were indecisive and whether future generations would be better off than the current $83 \%$ agreed, $4 \%$ were indecisive and $13 \%$ disagreed. The ones who disagreed saw future challenges leading to a decrease in quality of life. They also covered personal circumstances such as more pressure to perform, digitization and automation, more stress factors, less privacy and social life.

Everyone but one believes transforming the existing society into a sustainable society by 2050 is the right development of society and necessary to accomplish.

A slightly less strong believe can be observed when it comes to these suggestions regarding sustainable architecture and the question whether it should be seen as the new, central challenge of architecture and to play a part in it as young architects. The question "Do you feel adequately prepared and skilled?" gives an idea of the restraint responses: Only 13\% feel utterly qualified, $9 \%$ not at all and $78 \%$ feel only partly qualified. This majority stated they lack certain knowledge and most of their education stayed theoretic only - except for this course.

The experienced and applied approach from this course is seen as very helpful and goaloriented by $61 \%$ of the students, $30 \%$ think the taught approach is wrong and the remaining $9 \%$ believe the approach is partially helpful but use additional tools such as a window grid.

The following two questions went further into detail: "How would you, as (future) architects, deal with the dynamic appearance of an adaptive building (e.g. open and shut windows/ shading) to achieve an in your opinion appropriate design?" $77 \%$ want to show the dynamic appearance and even take it a step further and celebrate it; since they believe it shows people feel comfortable in the building. The other $23 \%$ prefer a static appearance of the façade and would rather hide the dynamic appearance. The next question asked for the 
opinion on integrating active solar systems to the building envelope. None disliked the idea or believed it could not be designed properly. Whereas $70 \%$ think BIPV is obligatory for building in the 21 st century and a carbon-free society in the future, $26 \%$ wants BIPV only hidden on roofs and $4 \%$ had some resentment still.

Finally, the students should decide on their preferred role as future architect between two alternatives: advisory expert leading the development or service provider fulfilling the wishes of the client. Three-quarters preferred the role of the leading expert and like the idea of architecture being a pioneer of development. One quarter does not believe they can determine the market and have to follow the client's wishes even if their personal opinion differs.

Overall the students agreed that our current generation is better off than the former but future generations might be facing some obstacles, when trying to continue the trend of improvement. Most see the need to develop a sustainable society and believe sustainable building is the key to build adequately in the 21 st century. Unfortunately, many do not feel properly trained e.g. to apply their theoretical knowledge to their designs, they reflect some of their education as partly superficially or when learning to design a sustainable approach may not even be appreciated by instructors. The acceptance of solar energy systems and a dynamic appearance of the façade is high or even desired. Three quarters of the students interviewed - to generalize even further- who think positively of sustainable building are those who would rather take up the role of leading experts than an indifferent service provider.

\section{REFERENCES}

[1] Eigbeonan, A., Sustainability and creativity methods: Agents of change in teaching the arch-design studio, Int. J. of Architecture and Urban Development, 5(3), 2015.

[2] Harder, E., ed., Writings in Architectural Education. Climate Change: Sustainability / Responsibility, EAAE Transaction on Architectural Education no. 47.

[3] Spiridonidis, C. \& Voyatzaki, M., eds., Educating Architects Towards Innovative Architecture, EAAE Transaction on Architectural Education no. 50.

[4] Kirsten, M., Ritz, M. \& Landeo, J., First short presentation of an office building, HCU Hamburg, Master 3. Semester, 2016.

[5] Dietrich, U. \& Poduje, P.C., Building design process: Design oriented or comfort oriented? Advanced Building Skins Conference, Bern, 2016, pp. 284-295.

[6] Public Works and Governments Services Canada, Daylighting Guide for Canadian Commercial Buildings, 2002, www.lightingassociates.org. Accessed on: 14 Jan. 2017.

[7] Ausschuss für Arbeitsstätten, Technische Regeln für Arbeitsstätten, Lüftung,ASR A3.6, 2012, www.baua.de. Accessed on:14 Jan. 2017.

[8] Rahmann, W., Pöthke, P. \& Liedtke, T., Second short presentation of an office building, HCU Hamburg, Master 3. Semester, 2016.

[9] Albers, A.L., Klinger, S., Posselt, M. \& Sawitzki, E., Second and third short presentation of an office building, HCU Hamburg, Master 3. Semester, 2016, 2017

[10] Rickert, S., Jamal, A. \& Weigand, J., Second and third short presentation of an office building, HCU Hamburg, Master 3. Semester, 2016, 2017.

[11] Gauss, M., Westermann, G. \& Spille, F., Second and third short presentation of an office building, HCU Hamburg, Master 3. Semester, 2016, 2017.

[12] Primero-Comfort, www.primerosoftware.de. Accessed on: 14 Jan. 2017.

[13] Koerner, K., Maass, S. \& Bassler, L., Third short presentation of an office building, HCU Hamburg, Master 3. Semester, 2017.

[14] Schwarz, H., Rimpf, V. \& Loebig, C., Third short presentation of an office building, HCU Hamburg, Master 3. Semester, 2017. 
[15] PV-GIS, http://re.jrc.ec.europa.eu/pvgis/apps4/pvest.php. Accessed on: 15 Jan. 2017.

[16] Directive 2010/31/EU of the European Parliament and of the Council of 19 May 2010 on the energy performance of buildings, http://eur-lex.europa.eu. Accessed on: 15 Jan. 2017.

[17] Buyukli, B., Buyukli, P., Koyuncu, S. \& Kurt, A., Third short presentation of an office building, HCU Hamburg, Master 3. Semester, 2017.

[18] GSW headquarter Berlin, picture: Ralf Roletschek, www.fahrradmonteur.de. Accessed on: 15 Jan. 2017.

[19] Alstercity building Hamburg, picture: U. Dietrich.

[20] Dietrich, U., Questionnaire My Dream Office, HCU Hamburg 2016.

[21] Posselt, M., Course Evaluation, HCU Hamburg, 2017. 